\title{
Perancangan dan Analisa Implementasi LTE Home pada Jaringan 4G LTE di Frekuensi $2300 \mathrm{Mhz}$
}

\author{
Asri Wulandari ${ }^{1 *}$, Toto Supriyanto ${ }^{2}$, Mohammad Itsnan $^{3}$ \\ ${ }^{1,2,3}$ Politeknik Negeri Jakarta, Jl GA Siwabessy Depok, Jakarta \\ *E-mail: asri.wulandari@elektro.pnj.ac.id
}

\begin{abstract}
Abstrak
Kebutuhan permintaan koneksi data pada pelanggan saat ini semakin meningkat. FTTx sebagai salah satu teknologi Fix broadband (FBB) mempunyai beberapa kelemahan terutama bila diterapkan pada wilayah rural. LTE Home sebagai sebuah teknologi smart home merupakan bentuk layanan teknologi WTTx 4G LTE yang diharapkan mampu memenuhi kebutuhan data pada pelanggan. Operator seluler mempunyai kesempatan menggunakan teknologi tersebut pada frekuensi $2300 \mathrm{MHz}$ dengan mode Time Divison Duplexing (TDD). Penelitian ini bertujuan merancang dan menganalisa implementasi LTE home dengan mengukur nilai QoS Class Identifier (QCI) dan nilai Radio Frekuensi Key Performance Indicator (RF KPI) guna meningkatkan kehandalan (realibility) jaringan untuk layanan komunikasi suara dan data. Parameter yang diukur adalah packet loss, delay, jitter, throughput untuk nilai QCI serta Radio Signal Received Power (RSRP) dan Radio Signal Received Quality (RSRQ) untuk nilai RF KPI. Hasil Pengukuran RF KPI didapatkan bahwa nilai untuk RSRP adalah 89dBm. Nilai ini tergolong baik karena sesuai dengan standart KPI yang telah ditetapkan, yaitu antara -70 sampai $-90 \mathrm{dBm}$. Untuk nilai RSRQ diperoleh sebesar -11dBM, hasil ini tergolong baik sesuai standart KPI yaitu $<-8 \mathrm{dBm}$. Hasil ini menunjukkan bahwa kualitas layanan jaringan 4GLTE yang disediakan untuk layanan implementasi LTE Home telah memenuhi standar nilai RF KPI. Sedangkan untuk parameter QCI diperoleh hasil bahwa baik voice call maupun video streaming, nilai masih memenuhi standar baik untuk nilai User Experience $K P I(Q C I)$ yaitu packet loss $<5 \%$, delay $<150 \mathrm{~ms}$ dan jitter $<75 \mathrm{~ms}$
\end{abstract}

Kata kunci: LTE home, RF KPI. QCI, RSRP, RSCP, packet loss, jitter

\begin{abstract}
The demand for data connections for customers is currently increasing. FTTx as one of the Fix broadband technology (FBB) has several weaknesses, especially when applied to rural areas. LTE Home as a smart home technology is a form of WTTX 4G LTE technology service that is expected to be able to meet the data needs of customers. This study aims to design and analyze the implementation of LTE home by measuring the value of QoS Class Identifier (QCI) and the value of Radio Frequency Key Performance Indicator (RF KPI) to improve network reliability for voice and data communication services. Some parameters measured are packet loss, delay, jitter, throughput for QCI values and Radio Signal Received Power (RSRP) and Radio Signal Received Quality (RSRQ) for RF KPI values. The results of RF KPI Measurement show that the value for RSRP is $-89 \mathrm{dBm}$. This value is quite good because it matches the predetermined KPI standard, which is between -70 to $-90 \mathrm{dBm}$. For RSRQ values obtained for -11 dBM, this result is classified as good according to the KPI standard which is <-8 dBm. These results indicate that the quality of 4GLTE network services provided for LTE Home implementation services has met RF KPI standard values. Whereas for the QCI parameters obtained results that both voice call and video streaming, the value still meets the standard Good for the User Experience KPI (QCI) value that is packet loss $<5 \%$, delay $<150 \mathrm{~ms}$ and jitter $<75 \mathrm{~ms}$
\end{abstract}

Keywords: LTE home, RF KPI. QCI, RSRP, RSCP, packet loss, jitter

\section{Pendahuluan}

LTE merupakan standar teknologi mobile broadband berbasis all IP yang dikeluarkan oleh 3GPP. LTE didesain sebagai teknologi $4 \mathrm{G}$ yang menyediakan multi megabit bandwidth, penggunaan jaringan radio secara efisien, pengurangan latency serta meningkatkan mobilitas dan kapasitas. Hal ini karena teknologi LTE mampu diimplementasikan secara bersama-sama dengan teknologi 2G/3G existing, sehingga pengoperasiannya menjadi low cost. Berbagai kelebihan tersebut bertujuan untuk meningkatkan interaksi pengguna jasa telekomunikasi ke jaringan, yang pada akhirnya memenuhi layanan wireless broadband (WBB) atau mobile broadband 
(MBB), seperti internet broadband, on line TV, social network dan interactive gaming [1].

Kebutuhan pemakaian koneksi data untuk melakukan komunikasi pada pelanggan saat ini semakin bertambah. Teknologi Fixed Broadband (FBB) dengan implementasi FTTH (Fiber to the Home)nya ternyata dirasakan mempunyai banyak kelemahan, terutama bila diaplikasikan di daerah pedesaan (rural). Kelemahan ini dicoba diatasi dengan pengembangan teknologi WBB (Wireless Broadband) [2]. Terdapat banyak kelebihan implementasi pada teknologi WBB yaitu kecepatan data yang tinggi, perkembangan yang cepat, pengembalian investasi dari sisi operator yang dirasakan cepat serta biaya yang mudah untuk pengembangan lebih lanjut [3]. Salah satu bentuk teknologi WBB yang akan diimplementasikan saat ini adalah bentuk WTTx (Wireless To the $X$ ) dengan bentuk LTE Home.

LTE Home merupakan layanan teknologi Wireless Broadband yang berbasis teknologi 4G LTE, sehingga mempunyai performansi yang jauh lebih baik dibandingkan teknologi akses jaringan fixed [4]. Jaringan 4G dengan teknologi terbaru Long Term Evolution (LTE) yang mempunyai kecepatan sampai 300 Mbps, menjadikan LTE sebagai teknologi 4G yang super cepat dibandingkan dengan generasi sebelumnya dan mampu melayani peningkatan layanan kebutuhan data. Teknologi jaringan 4G LTE dengan fitur-fitur canggih-nya memiliki kemampuan untuk bersaing secara luas pada perangkat mobile komunikasi, menyediakan berbagai layanan mobile dan kualitas komunikasi yang handal. Pada penelitian ini dilakukan perancangan dan analisa implementasi LTE Home pada jaringan 4G LTE di frekuensi 2300 MHz.Perancangan dan implementasi LTE Home dilakukan dengan merancang jaringan berbasis jaringan 4G LTE, kemudian akan dilakukan analisa kinerja sistem rancangan dengan mengukur performansi pelanggan saat menggunakan layanan voice dan data. Analisa dilakukan dengan mengukur parameter performansi berupa nilai packet loss, delay, jitter dan throughput dalam memberikan nilai quality of service (QoS) yang baik. Bentuk analisa performansi lainnya adalah menganalisa nilai kualitas radio frekuensi (RF) dengan mengukur nilai parameter Reference Signal Received Power (RSRP) dan nilai Reference Signal received Quality (RSRQ). Hasil yang diperoleh dari perancangan dan implementasi LTE Home bertujuan untuk mengukur dan menganalisa performansi implementasi LTE home pada jaringan 4G LTE agar sesuai dengan nilai key performance indicator (KPI) yang diharapkan yaitu $<5 \%$ untuk packet loss, $<=100 \mathrm{~ms}$ untuk nilai delay, sesuai nilai standar QoS Class Identifier (QCI) serta untuk RF KPI nilai RSRP > $-90 \mathrm{dBm}$ dan nilai RSRQ > $-8 \mathrm{~dB}$.

\section{Tinjauan Pustaka}

Long Term Evolution (LTE) merupakan teknologi berbasis IP yang dikeluarkan oleh 3GPP sebagai standar untuk komunikasi data nirkabel berkecepatan tinggi [5]. Sistem 4G LTE telah diperkenalkan sebagai versi terbaru teknologi mobile. 4G didefinisikan untuk memenuhi persyaratan yang ditetapkan oleh International Telecommunication Union (ITU) sebagai bagian dari IMTAdvanced [6]. Penggerak utama bagi evolusi arsitektur jaringan pada sistem 4G adalah : berbasis all-IP (Internet Protocol), mengurangi biaya jaringan, mengurangi latency data dan signalling, interworking mobility antara jaringan akses lainnya di 3GPP dan non-3GPP, always-on bagi user experience dengan kualitas layanan yang mendukung Quality of Services (QoS) dan kemampuan roaming di seluruh dunia [7].Arsitektur LTE dikenal dengan suatu istilah System Architecture Evolution (SAE) yang menggambarkan suatu evolusi arsitektur dibandingkan dengan teknologi sebelumnya. Secara keseluruhan LTE mengadopsi teknologi Evolved Packet System (EPS). Didalamnya terdapat tiga komponen penting yaitu UE (User Equipment), E-UTRAN (Evolved UMTS Terrestial Radio Access Network), dan EPC (Evolved Packet Core) [8].

Penggunaan frekuensi $2300 \mathrm{MHz}$ sebagai frekuensi kerja baru 4G LTE yang digelar oleh pemerintah untuk para operator, merupakan solusi yang tepat untuk memenuhi kebutuhan data pelanggan yang semakin besar. Pada 4G LTE penggunaan spektrum frekuensi 2300MHz diimplementasikan bersama dengan jaringan 4G LTE pada frekuensi $1800 \mathrm{MHz}$ yang sudah berjalan. Metode pemakaian bersama kedua frekuensi tersebut dilakukan dengan metode carrier agregation [9].

LTE Home merupakan layanan teknologi Wireless Broadband yang berbasis teknologi 4G LTE, merupakan bentuk layanan WBB yang dikenal sebagi teknologi WTTx (Wireless to the X). Teknologi WTTx mempunyai beberapa kelebihan dibandingan 
dengan teknologi FTTx yang sudah ada, yaitu [4] :

1. Mempunyai kecepatan data yang lebih tinggi bila dibandingan dengan fiber optik (FO)

2. Mampu meningkatkan wilayah jaringan (coverage area)

3. Mempunyai nilai cost yang trendah, sehingga mengurangi waktu dalam pemasaran (Lower Costs: Reduced Time to Market)

4. Pengembangannya lebih flexibel baik untuk wilayah Urban Area maupun Rural Area

5. Menghasilkan Comprehensive Services seperti pada Jaringan kabel (Wired Networks)

LTE Home dalam rancangan ini berbentuk sebuah perangkat Customer Premises Equipment (CPE) yang diletakkan pada sisi pelanggan, dimana sekaligus akan berfungsi sebagai sebuah wireless Router. Penempatan Perangkat CPE yang dilakukan pada rancangan sesuai dengan arsitektur jaringan 4G LTE dapat dilihat pada Gambar 1 sebagai berikut :

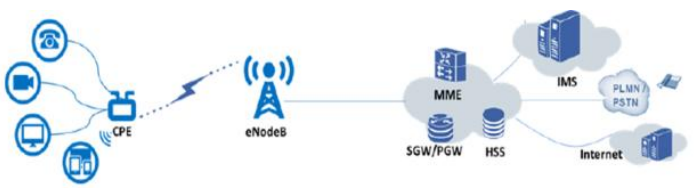

Gambar 1. Implementasi LTE home pada Jaringan 4G LTE (Huawei, 2017)

\section{Metodologi}

Inti penelitian ini adalah melakukan perancangan dan implementasi LTE Home pada jaringan 4G LTE $2300 \mathrm{MHz}$ dengan melihat parameter service KPI dan Radio Frekuensi KPI, untuk mengukur performansi dan kehandalan jaringan. Parameter yang diukur dan dianalisa adalah nilai packet loss, delay, jitter dan throughput untuk pengukuran service KPI, serta nilai RSRP dan RSRQ untuk pengukuran Radio frekuensi KPI. Software yang digunakan untuk pengambilan data performansi nilai service KPI adalah dengan menggunakan software wireshark dan Iperf, yang dilakukan pada beberapa skenario perancangan jaringan. Sedangkan pengukuran radio frekuensi KPI dilakukan dengan melakukan drive test menggunakan aplikasi GNET. Pengukuran nilai RSRP dan SINR akan diukur saat proses download dan upload dilakukan oleh pelanggan berdasarkan kecepatan pentranmisian yang dilakukan

Terdapat beberapa tahapan untuk perancangan dan optimasi jaringan komunikasi wireless ini, yaitu :

1. Menentukan parameter ukur terhadap perancangan implementasi LTE home,

2. Membuat skenario jaringan 4 G LTE sesuai dengan servis layanan (voice dan video) serta jumlah pengguna yang dilayani,

3. Mengimplementasikan LTE Home sesuai skenario yang dibuat dan mengukur nilai parameter QCI dan radio frekuensi parameter melalui metode drive test. ( State of the art : Perancangan dan implementasi LTE Home pada jaringan $4 \mathrm{G}$ LTE di frekuensi $2300 \mathrm{MHz}$ agar memberikan KPI yang baik

4. Hasil skenario tersebut kemudian disimulasikan dengan perangkat software wireshark dan dianalisa berdasar hasil yang diperoleh.

5. Menganalisa hasil pengukuran sebagai evaluasi apakah memenuhi standar kpi meliputi nilai user experience KPI maupun radio frequency KPI

Bentuk topologi jaringan yang dirancang untuk menganalisa dan mengevaluasi implementasi LTE home pada frekuensi $2300 \mathrm{MHz}$ dapat dilihat pada Gambar 2 berikut ini.
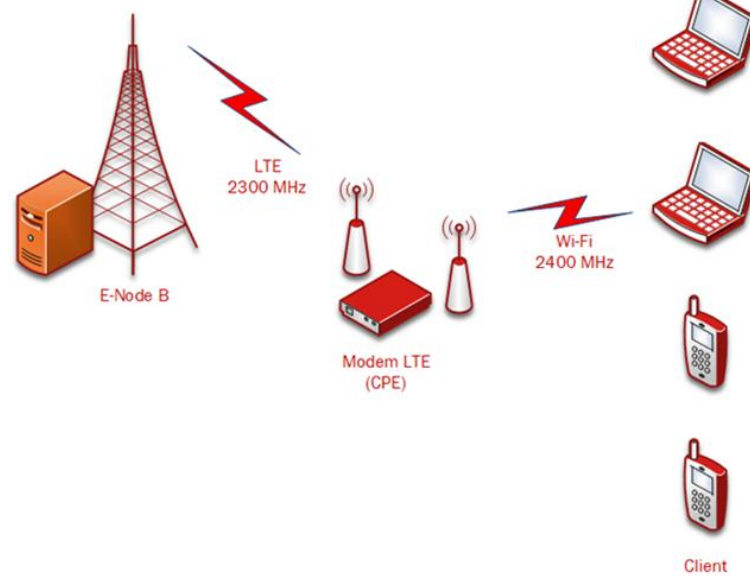

Gambar 2. Rancangan Topologi Jaringan LTE Home

Pada Gambar 2 terdapat beberapa komponen dalam topologi yang dirancang yaitu :

1. Modem LTE yang berfungsi sebagai CPE (Customer Premises Equipment). Modem ini akan terhubung ke eNodeB operator 
(Telkomsel) yang menyediakan layanan $4 \mathrm{G}$ LTE pada frekuensi $2300 \mathrm{Mhz}$.

2. Perangkat PC yang berfungsi sebagai client untuk melakukan komunikasi video dan voice melalui jaringan Wifi $2400 \mathrm{MHz}$ yang dikoneksikan pada jaringan LTE Home. Perangkat ini akan dikonfigurasikan sesuai dengan skenario yang telah dirasncang.

3. HP sebagai client yang berfungsi untuk mengukur kualitas layanan melalui drive test

4. Software Wireshark dan Iperf yang digunakan untuk mengukur dan menganalisa komunikasi suara dan video

5. Aplikasi GNET yang digunakan untuk mengukur kualitas RF KPI

\section{Hasil dan Pembahasan}

Berdasarkan perancangan awal, pengukuran performansi dilakukan untuk menilai dua (2) parameter yaitu nilai RF KPI (Radio frekuensi Key Performance Indicator) dan nilai QCI (QoS Class Identifier). Nilai RF KPI berkaitan dengan performansi kualitas jaringan, sedangkan nilai QCI merupakan nilai yang mengukur kualitas informasi yang dikrimkan baik informasi voice maupun video.

Secara lengkap hasil pengujian berdasar dari masing-masing parameter tersebut dapat dijelaskan sebagai berikut.

\section{Hasil pengujian Nilai Parameter RF KPI}

a. Pengukuran dari sisi Network (Router) Pengukuran nilai RF KPI dilakukan pada perangkat Router Huawei dan pada HP Client. Dari hasil pengukuran yang dilakukan terhadap perangkat router LTE Home Huawei yang digunakan, diperoleh hasil pengukuran seperti tampak pada Tabel 1 berikut ini.

Tabel 1. Hasil Pengujian RF KPI Router

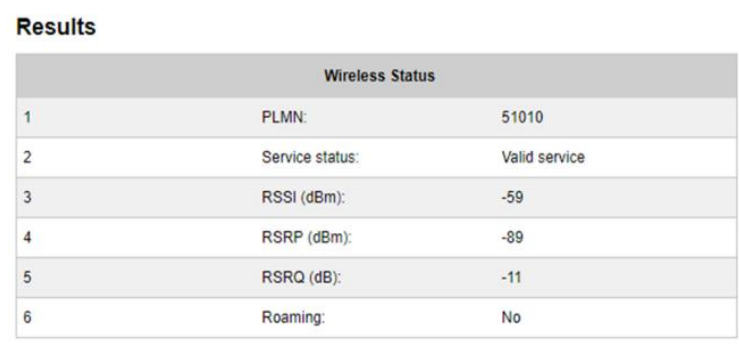

Dari tabel diatas terlihat bahwa nilai yang didapat untuk RSRP adalah $-89 \mathrm{dBm}$. Nilai ini tergolong baik karena sesuai dengan standart KPI yang telah disampaikan diatas, yaitu antara -70 sampai $-90 \mathrm{dBm}$.
Untuk nilai RSRQ diperoleh sebesar 11dBM, dan nilai ini juga tergolong baik sesuai standart KPI yaitu $<-8 \mathrm{dBm}$. Hasil ini menunjukkan bahwa kualitas layanan jaringan 4GLTE yang disediakan untuk layanan implementasi LTE Home telah memenuhi standar nilai RF KPI.

\section{b. Pengukuran dari sisi client}

Data untuk nilai parameter RF KPI juga didapatkan dengan melakukan pengukuran dari sisi user (client) menggunakan perangkat HP yang terkoneksi ke Jaringan 4G LTE. Pengukuran dilakukan dengan aplikasi GNET yang didownload pada HP. Data hasil pengukuran didapat melalui drive test. Hasil pengukuran tampak seperti Gambar 3 berikut ini.

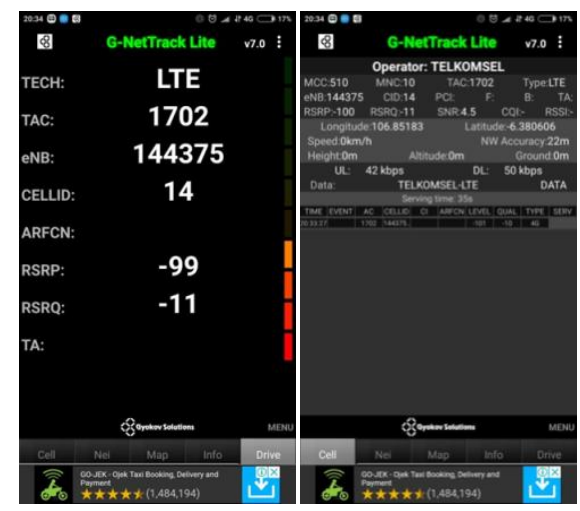

Gambar 3. Hasil RF KPI Pada Sisi Client

Dari Gambar 3 terlihat nilai yang didapat untuk RSRP adalah $-99 \mathrm{dBm}$. Nilai ini tergolong sedang karena sesuai dengan standart KPI yang telah disampaikan diatas, yaitu antara -90 sampai $-100 \mathrm{dBm}$. Untuk nilai RSRQ diperoleh sebesar -11dBM, dan nilai ini juga tergolong baik sesuai standart KPI yaitu $<-8 \mathrm{dBm}$. Hasil ini menunjukkan bahwa kualitas layanan jaringan 4GLTE yang disediakan untuk layanan implementasi LTE Home telah memenuhi standar nilai RF KPI.

\section{Hasil Pengujian Nilai Parameter QCI}

Dalam melakukan pengujian QCI tahap awal adalah menentukan konfigurasi topologi pengujian untuk voice call dan video, seperti tampak pada Gambar 4 berikut ini 


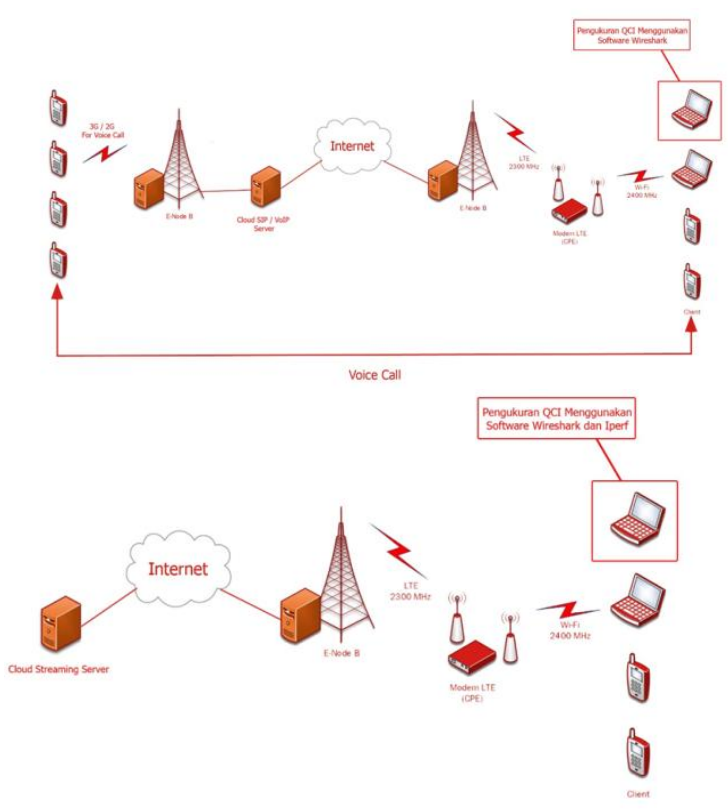

Gambar 4. Konfigurasi Pengujian layanan Voice Call dan Video Streaming

Dari konfigurasi diatas, data hasil pengukuran untuk nilai parameter QCI diperoleh berdasarkan pengukuran pada layanan yang diberikan pada pelanggan (user) yaitu layanan voice call dan layanan video streaming.

\section{a. Data dan Analisa Data Video Streaming}

Untuk melakukan pengukuran data saat melakukan video streaming dilakukan dengan berdasarkan skenario jumlah user yang melakukan video straming. Data berikut menunjukkan hasil pengukuran saat proses video streaming dilakukan oleh 1 client, 2 client, 3 client, 4 client sampai 5 client. Masing-masing data yang diperoleh dapat dilihat pada Gambar 5 sampai dengan Gambar 8 berikut ini.

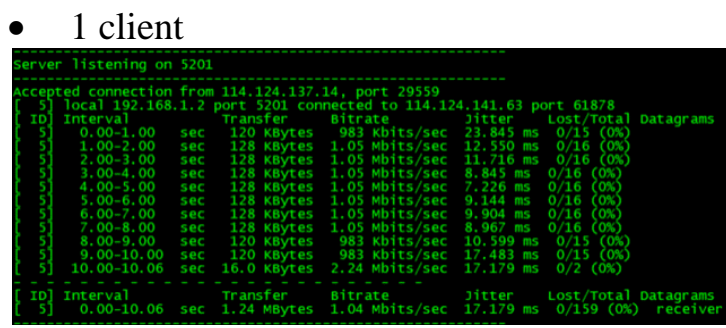

Gambar 5. Hasil Video Streaming untuk 1 client

- 2 client

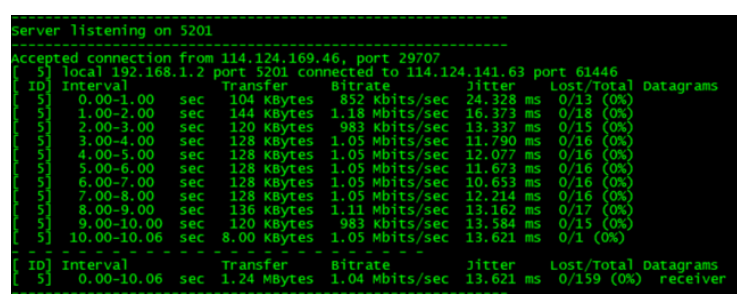

Gambar 6. Hasil Video Streaming untuk 2 client

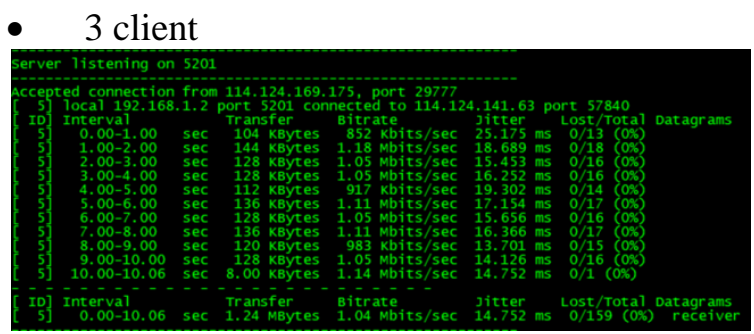

Gambar 7. Hasil Video Streaming untuk 3 client

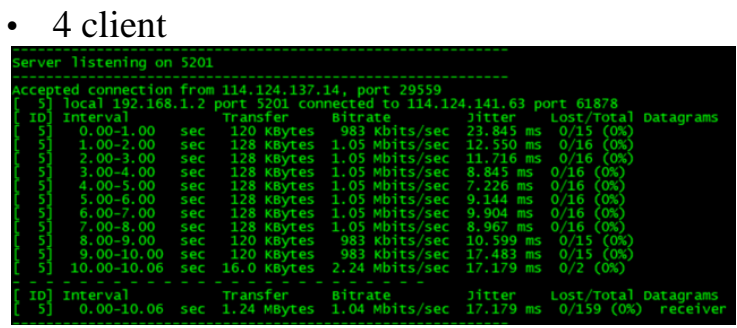

Gambar 8. Hasil Video Streaming untuk 4 client

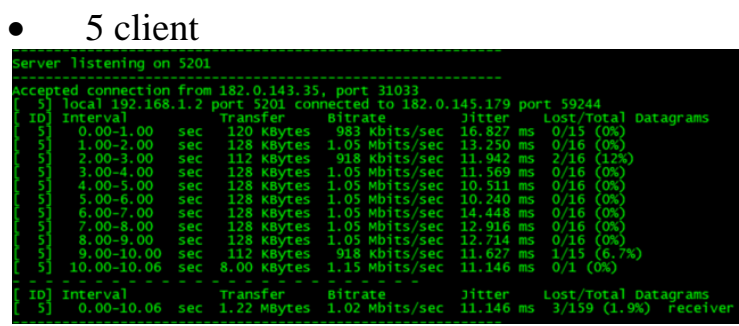

Gambar 9. Hasil Video Streaming untuk 5 client

b. Data dan Analisa Data Voice Call

Untuk melakukan pengukuran data saat melakukan voice call juga dilakukan dengan berdasarkan skenario jumlah user yang melakukan voice call. Data berikut menunjukkan hasil pengukuran saat proses Voice call dengan jumlah 1 panggilan, 2 panggilan, 3 panggilan, sampai 4 panggilan.Masing-masing data yang diperoleh dapat dilihat pada Gambar 10 sampai dengan Gambar 13 berikut ini.

- 1 panggilan 


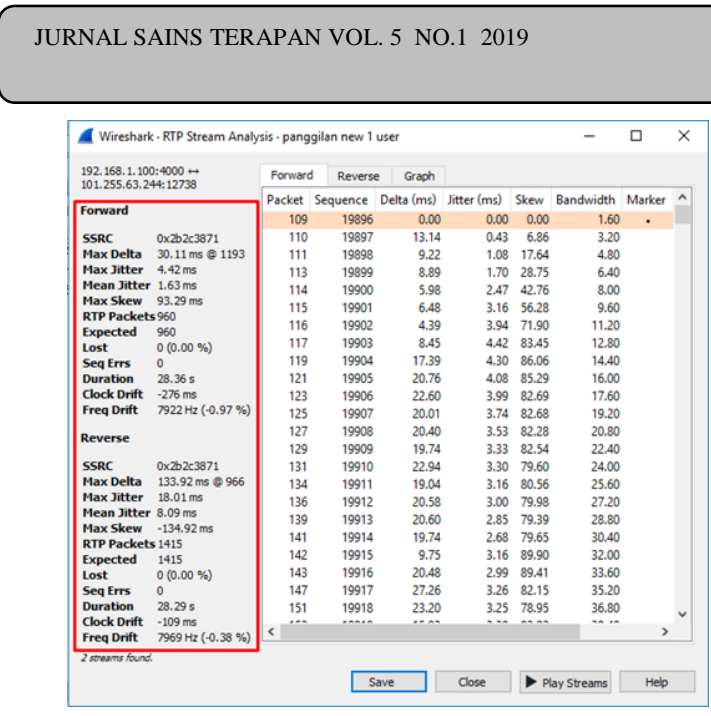

Gambar 10. Data Voice Call 1 panggilan

- 2 panggilan

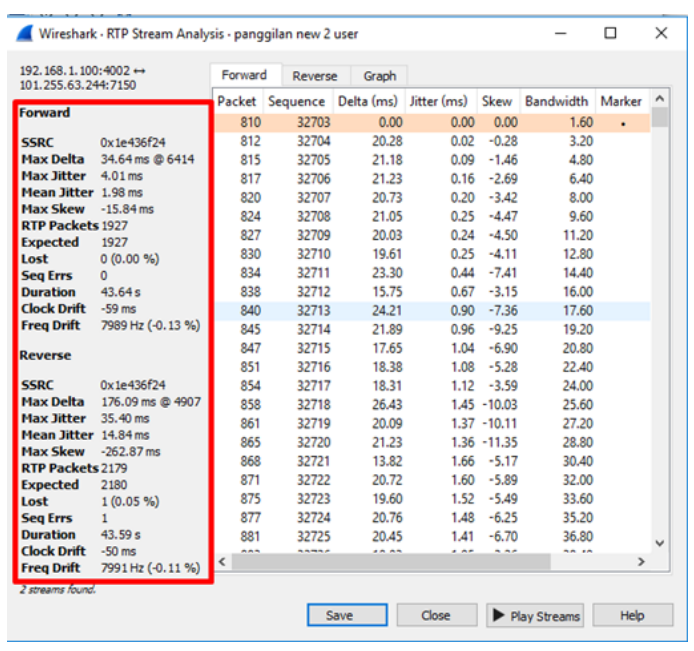

Gambar 11. Data Voice Call 2 panggilan

- 3 panggilan

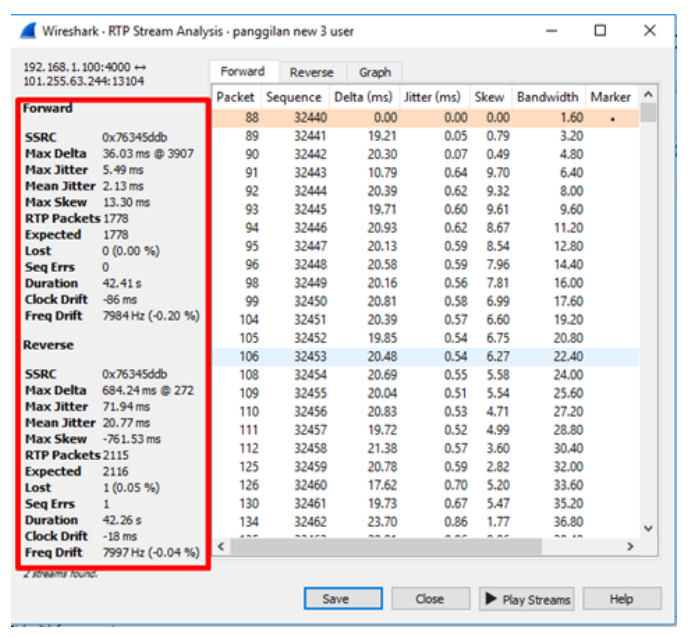

Gambar 12. Data Voice Call 3 panggilan

- 4 panggilan

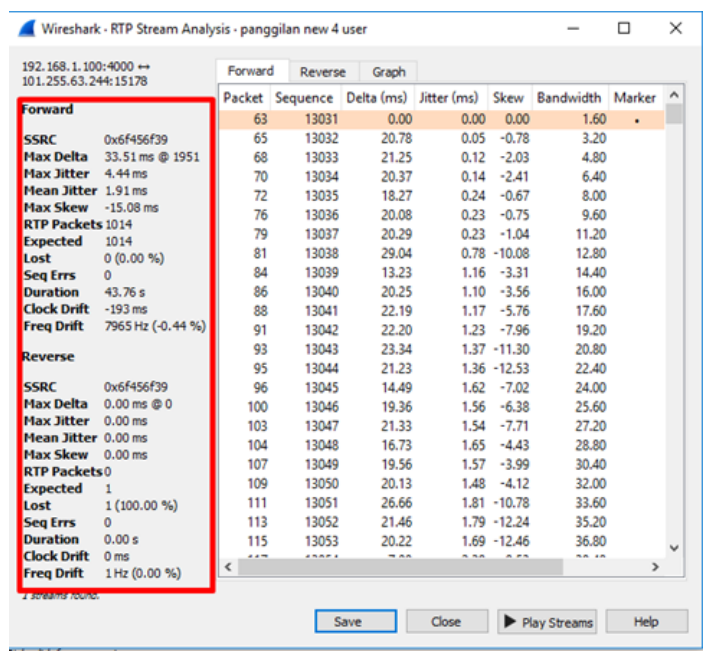

Gambar 13. Data Voice Call 4 panggilan

Dari keseluruhan data yang didapatkan dari kedua jenis layanan video streaming dan voice call, dapat dinyatakan dalam bentuk tabel seperti yang terlihat pada Tabel 2 dan Tabel 3. berikut ini.

Tabel 2. Hasil QCI untuk Voice Call

\begin{tabular}{lclll}
\hline \multirow{2}{*}{$\begin{array}{c}\text { Jumlah } \\
\text { panggilan }\end{array}$} & \multicolumn{4}{c}{ Hasil Akhir } \\
\cline { 2 - 5 } & Delay & Jitter $\begin{array}{c}\text { Packet } \\
\text { Loss }\end{array}$ & Throughput \\
\hline 1 & $24.768 \mathrm{~ms}$ & $\begin{array}{l}4.86 \\
\mathrm{~ms}\end{array}$ & $0 \%$ & $143 \mathrm{Kbps}$ \\
& & & & \\
2 & $21.326 \mathrm{~ms}$ & $\begin{array}{l}8,41 \\
\mathrm{~ms}\end{array}$ & $0.05 \%$ & $161 \mathrm{Kbps}$ \\
3 & & & & \\
& $21.917 \mathrm{~ms}$ & $\begin{array}{l}11,45 \\
\mathrm{~ms}\end{array}$ & $0.05 \%$ & $157 \mathrm{Kbps}$ \\
4 & & 3.61 & $0.09 \%$ & $123 \mathrm{Kbps}$ \\
& & $\mathrm{ms}$ & &
\end{tabular}

Dari data pengukuran nilai QCI untuk voice call diatas terlihat bahwa nilai masih memenuhi standar Baik untuk nilai User Experience KPI (QCI) yaitu packet loss $<5 \%$, delay $<150 \mathrm{~ms}$ dan jitter $<75 \mathrm{~ms}$.

Tabel 3. Hasil QCI untuk Data Streaming

\begin{tabular}{lcccc}
\hline \multirow{2}{*}{$\begin{array}{c}\text { Jumlah } \\
\text { User }\end{array}$} & Delay & Jitter & $\begin{array}{c}\text { Packet } \\
\text { Loss }\end{array}$ & Throughput \\
\cline { 2 - 5 } & & & & \\
\hline 1 & $287 \mathrm{~ms}$ & $\begin{array}{l}12.223 \\
\mathrm{~ms}\end{array}$ & $0 \%$ & $167 \mathrm{Kbps}$ \\
2 & $309 \mathrm{~ms}$ & $\begin{array}{l}13.621 \\
\mathrm{~ms}\end{array}$ & $0 \%$ & $167 \mathrm{Kbps}$ \\
3 & & $\begin{array}{l}14.752 \\
\mathrm{~ms}\end{array}$ & $0 \%$ & $167 \mathrm{Kbps}$ \\
& $320 \mathrm{~ms}$ & &
\end{tabular}




\begin{tabular}{|c|c|c|c|c|}
\hline \multicolumn{5}{|c|}{ JURNAL SAINS TERAPAN VOL. 5 NO. 12019} \\
\hline 4 & $362 \mathrm{~ms}$ & $\begin{array}{l}17.179 \\
\mathrm{~ms}\end{array}$ & $0 \%$ & $166 \mathrm{Kbps}$ \\
\hline 5 & $722 \mathrm{~ms}$ & $\begin{array}{l}11.146 \\
\mathrm{~ms}\end{array}$ & $1.9 \%$ & $164 \mathrm{Kbps}$ \\
\hline
\end{tabular}

Dari data pengukuran nilai QCI untuk video streaming diatas didapatkan hasil Baik , karena memenuhi standar baik untuk nilai User Experience KPI (QCI) yaitu packet loss < $5 \%$, delay $<150 \mathrm{~ms}$ dan jitter $<75 \mathrm{~ms}$

Dengan demikian implementasi LTE Home pada Jaringan 4G LTE telah memenuhi standar kualitas layanan KPI yang terdiri atas nilai RF KPI maupun untuk nilai User Eksperience KPI dengan hasil Baik, sehingga cocok dan tepat diimplementasikan untuk memenuhi kebutuhan pelanggan akan layanan suara dan data

\section{Kesimpulan}

Penelitian ini berhasil melakukan perancangan dan implementasi LTE Home pada jaringan 4G LTE di frekuensi $2300 \mathrm{MHz}$. Analisa performansi perancangan dan implementasi dilakukan dengan melakukan pengukuran dua parameter yaitu parameter nilai kualitas radio frekuensi (RF) KPI dengan mengukur nilai Reference Signal Received Power (RSRP) dan nilai Reference Signal received Quality (RSRQ), serta parameter nilai QCI (QOS Class Identifier) dengan mengukur nilai packet loss, jitter dan delay. Pengukuran kedua nilai parameter tersebut dilakukan pada dua jenis layanan yaitu video streaming dan voice call. Hasil Pengukuran RF KPI didapatkan bahwa nilai yang didapat untuk RSRP adalah $-89 \mathrm{dBm}$. Nilai ini tergolong baik karena sesuai dengan standart KPI yang telah distandarkan, yaitu antara -70 sampai -90 $\mathrm{dBm}$. Untuk nilai RSRQ diperoleh sebesar 11dBM, dan nilai ini juga tergolong baik sesuai standart KPI yaitu $<-8 \mathrm{dBm}$. Hasil ini menunjukkan bahwa kualitas layanan jaringan 4GLTE yang disediakan untuk layanan implementasi LTE Home telah memenuhi standar nilai RF KPI. Sedangkan untuk parameter QCI diperoleh hasil bahwa baik voice call maupun video streaming, nilai masih memenuhi standar Baik untuk nilai User Experience KPI (QCI) yaitu packet loss $<5 \%$, delay $<150 \mathrm{~ms}$ dan jitter $<75 \mathrm{~ms}$.

\section{Saran}

Penelitian lebih lanjut dapat dilakukan dengan memvariasikan metode pengukuran yang dilakukan, melakukan perbandingan hasil pengukuran dan menganalisanya untuk menentukan metode yang paling tepat dalam pengukuran implementasi LTE home pada frekensi $2300 \mathrm{MHz}$

\section{Ucapan Terimakasih}

Ucapan terima kasih kami sampaikan kepada kampus Politeknik Negeri Jakarta, Laboratorium Telekomunikasi PNJ dan PT. Telekomunikasi Seluler Indonesia yang mensupport pelaksanaan penelitian ini.

\section{Daftar Pustaka}

[1] . Ariyanti, Sri."Studi Perencanaan Jaringan LTE Area Jabodetabek Studi Kasus PT. Telkomsel". Buletin Pos dan Telekomunikasi Vol 12. No. 4 Desember (2014) :255-268.

[2]. Huawei. " $4 \mathrm{G}$ Wireless Broadband Industri White Paper V1.0." ITU Telecom World (2017)

[3]. Zou, Youngxi. "The Future Radio Access Technology". IEEE WCNC (2017), San Fransisco, CA

[4]. Liu, Gungyi. "WTTx : One way to Monetize the Large Bandwidth." China Mobile (2017)

[5]. Pranoto, Slamet. "Pengukuran Performansi Jaringan 4G LTE",Buletin PT. Telekomunikasi Seluler (2015)Oktober 2015,Jakarta

[6]. Ariyani, Sovia. "Evaluasi Kualitas Layanan (QoS) Jaringan Data Seluler pada Teknologi 4G LTE". Jurnal Penelitian IPTEKS Juli (2016) :26-42

[7]. Wulandari, Asri. "Perancangan dan Optimasi Implementasi Small Cell pada Jaringan 4G LTE di Frekuensi 1800 MHz". Proceedings of SNTEI Politeknik Negeri Ujung Pandang, November (2017) ISSN 987-602- 2-0 : 13-19

[8]. Hikmaturokhman, Alfin, and Achmad Rizal Danisya. "4G LTE $1800 \mathrm{MHz}$ Coverage and Capicity Network Planning Using Frekuensi Reuse 1 Model for Rural Area in Indonesia". Proceedings of the $6^{\text {th }}$ International 
Conference on Software and Computer Applications (2017), ACM.

[9]. Chaerunisa, Andi. "Analisa Optimasi Coverage Jaringan LTE TDD pada Frekuensi $2300 \mathrm{MHz}$ Di Wilayah DKI Jakarta". Proceedings of Seminar Nasional Inovasi dan Aplikasi Teknologi di Industri (2017), ITN, Malang. ISSN 2085-4218 : B8.1 - B8.7.

[10] . Wati, Anggar. "Design Penggunaan QoS pada Layanan Video Conference Point to Point dan Multipoint dengan Metode Kompresi Codec H.264 pada Jaringan 4G”. Proceedings of Seminar Nasional Inovasi dan Aplikasi Teknologi di Industri (2018), ITN, Malang. ISSN 2085-4218 : 37 - 42.

[11] . Huawei, "Product Description, Huawei E5172As-22 LTE CPE". Huawei Technologies (2013) Huawei

Technologies Co., Ltd 